\title{
IODINE NUMBER OF WOOL: A METHOD FOR DETERMIN- ING THE ACTION OF VARIOUS CHEMICAL REAGENTS ON WOOL AND OTHER PROTEINS
}

\author{
By Milton Harris, Harvey A. Neville, and William C. Fritz ${ }^{1}$
}

\section{ABSTRACT}

The purpose of this research was to find a method for determining the action of various chemical reagents upon wool. The iodine number provides a qualitative measure of the extent to which the amino groups are affected by various treatments of the protein.

Amino acids and proteins exhibit iodine numbers as determined by the standard method. The iodine numbers of such substances do not indicate ordinary unsaturation but are shown to be related to the free amino nitrogen content.

The iodine numbers of some typical proteins are reported and a general correspondence between the iodine numbers and the isoelectric points of the proteins is shown.

Conversion of amino groups to hydroxyl groups, combination of amino groups with strong acids, and other chemical reactions which affect the amino groups reduce the iodine numbers of amino acids (with the exception of cysteine) to zero.

Part of the iodine number of wool is shown to be due to cysteine which is very susceptible to oxidation. The iodine number of wool is therefore affected by reactions of chemical reagents with the amino or the cysteine groups.

This method will distinguish, for example, between reversibly adsorbed and chemically combined acid. The latter can be removed by the action of an alkali and this restores the original iodine number of the wool.

\section{CONTENTS}

Page

I. Introduction

II. Methods

III. Results and discussion

1. Amino acids and derivatives

2. Proteins

3. Wool

IV. References.

\section{INTRODUCTION}

The term "iodine number" is ordinarily associated with oils and fats for which it serves as a measure of chemical unsaturation. It represents the number of centigrams of iodine which combine with 1 gram of material.

1 The experimental part of this research was done by William C. Fritz, Eavenson and Levering, Research Fellow at Lehigh University. The work was directed by Harvey A. Neville, Associate Professor of Chemistry at Lehigh University, and Milton Harris, Research Associate at the Bureau of Standards from the American Association of Textile Chemists and Colorists. The latter's contribution to this study forms a part of the study of wool being undertaken by the Association on a grant from the Textile Foundation. 
The aliphatic amino acids are saturated compounds, but they nevertheless exhibit definite and reproducible iodine numbers which may be determined by the same methods as those used for fats and oils. The experimental evidence indicates that the iodine reacts only with the free amino groups in these compounds, unless, like cysteine, for example, they contain readily oxidizable groups which also react.

The iodine numbers of proteins may be determined by the same method used for oils and a part, at least, of the iodine number of each protein may be attributed to the free amino groups. This provides a useful means of determining the extent to which these groups are affected by various treatments of the protein.

This paper is a report of a brief survey on the use of this method for studying the action of various chemical reagents upon wool.

\section{METHODS}

The iodine numbers reported here were obtained by a slight modification of the standard Wijs method $(1),{ }^{2}$ using a solution of iodine monochloride in glacial acetic acid, which was 0.1 normal with respect to total halogen. Samples of the amino acids or their derivatives weighing about 0.1 gram and of the proteins weighing about 0.5 gram were used for each determination.

The wool fibers were prepared by cutting them into very short lengths. The iodine number of the cut fibers was identical with that obtained from powdered wool. All samples were conditioned at a relative humidity of 65 percent $(70 \mathrm{~F})$. Conditioned and dried samples gave the same iodine number calculated on the basis of the wool protein.

The determinations of iodine numbers were carried out as follows: A weighed sample was placed in a flask and $25 \mathrm{ml}$ of glacial acetic acid was added. Twenty-five ml of Wijs solution was added and the mixture was allowed to stand, with occasional shaking, for one half hour at $25 \mathrm{C}$. At the end of this time, $50 \mathrm{ml}$ of water and $20 \mathrm{ml}$ of a 15 percent solution of potassium iodide were added. Sodium thiosulfate solution was then added in an amount equal to that required by a blank determination. After the solution had stood for one half hour, $10 \mathrm{ml}$ of a 1 percent starch solution was added and the excess of thiosulfate was titrated with a standard iodine solution. This modification, namely, the addition of excess thiosulfate and reverse titration with iodine, was used in all of the determinations of iodine numbers. By this procedure all of the iodine was removed from the wool fibers and the wool appeared as white as the original sample.

Analyses of wool samples which had been used for iodine number determinations showed that no chlorine or iodine remained in combination with the wool after the thiosulfate treatment. This indicates that the halogen which combined with the wool in the Wijs solution was removed by the aqueous solutions in some combined form and not as free iodine, since it did not react with its equivalent of thiosulfate.

\footnotetext{
${ }^{2}$ Figures in parentheses here and throughout the text refer to the references given at the end of this paper, page 809 .
} 


\section{RESULTS AND DISCUSSION}

\section{AMINO ACIDS AND DERIVATIVES}

The iodine numbers of a few amino acids and derivatives determined by the above method are recorded in table 1 .

TABLE 1.-Iodine numbers of a few amino acids and derivatives

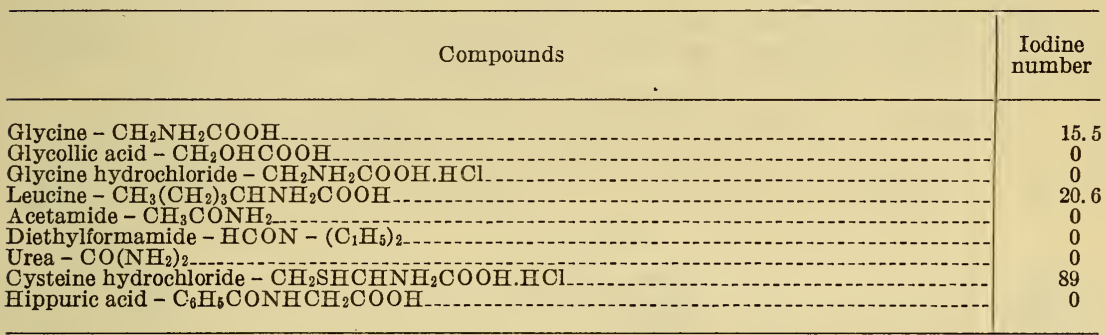

A simple amino acid such as glycine gives an iodine number while the corresponding hydroxy acid does not react with iodine and gives no iodine number. Further evidence that the iodine reacts only with the free amino group is offered by the fact that acid salts of the amino acids, such as the hydrochloride, likewise give no iodine number. However, the reaction of halogen with the simple amino acids is by no means complete under the conditions of these experiments since the theoretical iodine numbers of glycine and leucine, assuming a stoichiometric reaction, would be 338 and 194, respectively. It is obvious that the study of other factors such as $\mathrm{pH}$ values and molecular concentrations are necessary, if this method is to be made strictly quantitative. As the molecular weight of the amino acid increases, the reaction with iodine becomes more nearly complete and, as will be shown it is approximately stoichiometric for some of the proteins.

The hydrochloride of cysteine should give a zero iodine number if the reactions were limited to free amino groups. However, this particular amino acid contains the easily oxidizable-SH group which reacts with iodine to produce cysteine. The theoretical iodine number of cysteine hydrochloride corresponding to the reaction $2 \mathrm{R} . \mathrm{CH}_{2} \mathrm{SH}+$ $\mathrm{I}_{2}=\mathrm{R} \cdot \mathrm{CH}_{2} \mathrm{~S}-\mathrm{SCH}_{2} \cdot \mathrm{R}+2 \mathrm{HI}$ is 83 . The value given in table 1 is in fairly good agreement in view of the difficulties attending the use of this reaction for the quantitative estimation of cysteine as reported by Lucas and King (2).

Since acetamide, hippuric acid, and similar amides give no iodine numbers, it may be concluded that the amide nitrogen does not contribute to the iodine number of a protein.

Reaction of iodine with the amino group may involve either an addition or an oxidation reaction. It may be assumed by analogy that the addition of iodine (or chlorine) from the Wijs solution occurs at the amino group in a manner similar to the addition of hydrochloric acid. The mode of combination of acids with amino groups has recently been discussed by Phillips (3), who represents the chlorine or other anion as bound to the molecule through an atom of hydrogen having four electrons in its shell. A similar structure may be used 
to represent the combination of the amino group with two halogen atoms instead of with hydrochloric acid.

Since the Wijs solution is also an oxidizing agent, it is possible that the amino group has been at least partially oxidized during the iodine number determination (4).

\section{PROTEINS}

In table 2 are recorded the iodine numbers of some proteins. While it is not desired to place any emphasis upon iodine numbers as a means of comparing different proteins, a general relationship is evident.

TABLE 2.-Iodine numbers and isoelectric points of a few proteins

\begin{tabular}{|c|c|c|c|}
\hline Protein & Source & $\begin{array}{l}\text { Isoelectric } \\
\text { point }\end{array}$ & $\begin{array}{l}\text { Iodine } \\
\text { number }\end{array}$ \\
\hline $\begin{array}{l}\text { Fibroin } \\
\text { Keratin } \\
\text { Gelatin-1 } \\
\text { Zein } \\
\text { Gliadin }\end{array}$ & $\begin{array}{l}\text { Degummed silk } \\
\text { Texas wool } \\
\text { Food } \\
\text { Corn } \\
\text { Wheat. }\end{array}$ & $\begin{array}{l}2.5(5) \\
3.4(6) \\
4.7(7) \\
6.2(8) \\
6.5(8)\end{array}$ & $\begin{array}{r}3.7 \\
14.2 \\
10.2 \\
27.5 \\
25.0\end{array}$ \\
\hline
\end{tabular}

Fibroin which has a low content of free amino nitrogen and an isoelectric point at a relatively high acidity, has a low iodine number. On the basis of isoelectric points and the accepted values for free amino nitrogen, wool keratin should be next in order with an iodine number less than that of gelatin. The apparent inconsistency in table 2 is readily explained by the fact that keratin is the only protein with an appreciable sulphur content, a portion of which is present as cysteine, which, as we have shown, reacts readily with iodine. Therefore, only a portion of the iodine number of wool is due to the amino nitrogen content of keratin. Zein and gliadin exhibit high iodine numbers and are reported to have isoelectric points at relatively high $\mathrm{pH}$ values.

The experimentally determined iodine numbers of silk, wool, and gelatin are in fair agreement with the calculated values assuming stoichiometric reaction with the amino groups. These values are compared in table 3. Zein (8) is reported to contain no free amino nitrogen and gliadin to contain only $1.9 \mathrm{mgs}$ of amino nitrogen per gram of protein. For these the calculated iodine numbers are much lower than the experimental ones.

TABLE 3.-Comparison of the experimental iodine number with calculated iodine numbers assuming stoichiometric reaction with the amino groups

\begin{tabular}{|c|c|c|c|}
\hline Protein & $\begin{array}{l}\text { Amino nitro- } \\
\text { gen per } \mathrm{g}\end{array}$ & \multicolumn{2}{|c|}{ Iodine number } \\
\hline $\begin{array}{l}\text { Silk } \\
\text { Wool Do } \\
\text { Dolatin } \\
\text { Gein } \\
\text { Gliadin }\end{array}$ & $\begin{array}{c}m g \\
1.5-1.7(9) \\
5.7(10) \\
9.2(11) \\
5.5(12) \\
0 \quad(12) \\
1.9(13)\end{array}$ & $\begin{array}{r}\text { Calculated } \\
2.7-3.1 \\
10.3 \\
16.7 \\
9.9 \\
0 \\
3.4\end{array}$ & \begin{tabular}{r} 
Experimental \\
3.7 \\
a $8.3-9.4$ \\
\hdashline 10.2 \\
27.5 \\
25.0
\end{tabular} \\
\hline
\end{tabular}

a These are corrected values, obtained by subtracting that portion of the iodine number due to reaction with the cysteine group from the iodine number of untreated wool. Reference to table 4 shows that the action of nitrous acid or formaldehyde upon wool lowers the iodine number 8.3 to 9.4 units. Since these reagents may be presumed to react with the free amino groups but not with the cysteine sulphur, the portion of the iodine number of wool due to amino nitrogen appears to be of this order. 
TABLE 4.-Iodine numbers of raw wool and wool treated with various chemical reagents

\begin{tabular}{|c|c|c|}
\hline $\begin{array}{l}\text { Experi- } \\
\text { ment no. }\end{array}$ & Treatment & $\begin{array}{c}\text { Iodine } \\
\text { no. }\end{array}$ \\
\hline 1 & Raw wool - scoured with solvents and rinsed & 14. 2 \\
\hline 2 & Overscoured - 1 percent soda ash, $70 \mathrm{C}$. & 14.2 \\
\hline 3 & Formaldehyde, 1 percent solution & 5.9 \\
\hline 4 & Neutral $\mathrm{H}_{2} \mathrm{O}_{2}, 1$ percent solution.. & 14.1 \\
\hline 5 & $\mathrm{NH}_{2} \mathrm{SO}_{4}$ & 7.2 \\
\hline $\begin{array}{l}6 \\
7\end{array}$ & $\begin{array}{l}\text { Acid } \mathrm{H}_{2} \mathrm{O}_{2}, 1 \text { percent solution in } \mathrm{NH}_{2} \mathrm{SO}_{4} \\
\text { Treatment } 5 \text {, followed by } \mathrm{Na}_{2} \mathrm{CO}_{3} \text { solution..... }\end{array}$ & $\begin{array}{r}7.2 \\
14.2\end{array}$ \\
\hline 8 & Ammoniacal $\mathrm{H}_{2} \mathrm{O}_{2}, 1$ percent solution & 4. 3 \\
\hline 9 & Alkaline $\mathrm{H}_{2} \mathrm{O}_{2}, 1$ percent solution ( 0.5 percent $\mathrm{Na}_{2} \mathrm{CO}_{3}$ ) & 5.3 \\
\hline 10 & Acid solution of $\mathrm{KMnO}_{4}, 1$ percent, 8 hours & 1.5 \\
\hline $\begin{array}{l}11 \\
12\end{array}$ & $\begin{array}{l}\text { Solution } \mathrm{HNO}_{2}, 0.1 \text { percent, } 25 \mathrm{C} \\
\text { Solution } \mathrm{HNO}_{2}, 0.1 \text { percent, } 0 \text { C. }\end{array}$ & $\begin{array}{l}4.7 \\
4.8\end{array}$ \\
\hline & & \\
\hline
\end{tabular}

\section{WOOL}

Samples of raw wool were treated with various chemical reagents and their iodine numbers were determined, with the results shown in table 4. A comparison of the iodine numbers in experiments 1 and 2 demonstrates that overscouring the wool, for example, by increasing the temperature and the concentration of alkali to such an extent that the wool is damaged in appearance and harshened, does not affect either the content of cysteine sulphur or of amino nitrogen.

In the neutral solution (experiment 4) hydrogen peroxide does not affect the iodine number. In the acid solution (experiment 6) peroxide has the same effect as that produced by the acid alone under the same conditions (experiment 5) and this effect is entirely removed by neutralization (experiment 7). In contrast, the alkaline peroxide solutions (experiments 8 and 9 ) lower the iodine number to a marked degree. These results indicate that in neutral and acid solutions hydrogen peroxide oxidizes neither the cysteine sulphur nor the amino groups in wool, while in alkaline solutions, hydrogen peroxide apparently attacks both groups to a limited extent.

A stronger oxidizing agent, potassium permanganate (experiment 10) lowers the iodine number to a greater degree than any other reagent used, but the wool is severely damaged by this treatment.

A solution of nitrous acid would be expected to lower the iodine number of wool by converting amino groups to hydroxyl groups. Nitrous acid may also oxidize the cysteine sulphur in wool. The iodine numbers in experiments 11 and 12 in table 3 were obtained after 3 hours' treatment with 0.1 percent solutions of nitrous acid. Higher concentrations or longer treatments do not produce appreciably lower iodine numbers, but cause an increased yellowing of the wool, especially at temperatures above $0 \mathrm{C}$.

While acid lowers the iodine number, as already pointed out, if it is removed by an alkaline treatment the iodine number returns to the original value. This complete neutralization or removal of combined acid is accomplished only by soaking the acid-treated wool for a considerable time in an excess of the alkaline solution. Merely titrating rapidly to the phenolphthalein and point does not remove all of the combined acid. The evidence that a definite amount of acid combines chemically with wool and cannot be removed by mere 
rinsing with water is illustrated in figure 1 . Here it is shown that prolonged rinsing alone removes only a portion of the acid, while all the acid remaining on the wool may be readily removed by neutralization, after which the iodine number of the wool returns to its original value. Since it has been shown that the iodine number bears an inverse relationship to the amount of acid on the wool, the minimum difference between the curves may be taken as a measure of the chemically combined acid in the unneutralized wool.

It is well known that strong alkalis, even in very dilute solution, have an injurious action upon wool and that somewhat more concentrated solutions will destroy the wool fibers, dissolving or dispersing and hydrolyzing the keratin. Figure 2 illustrates the effects upon the iodine number and upon the amino nitrogen content of wool resulting from the action of 0.5 normal sodium hydroxide solution at

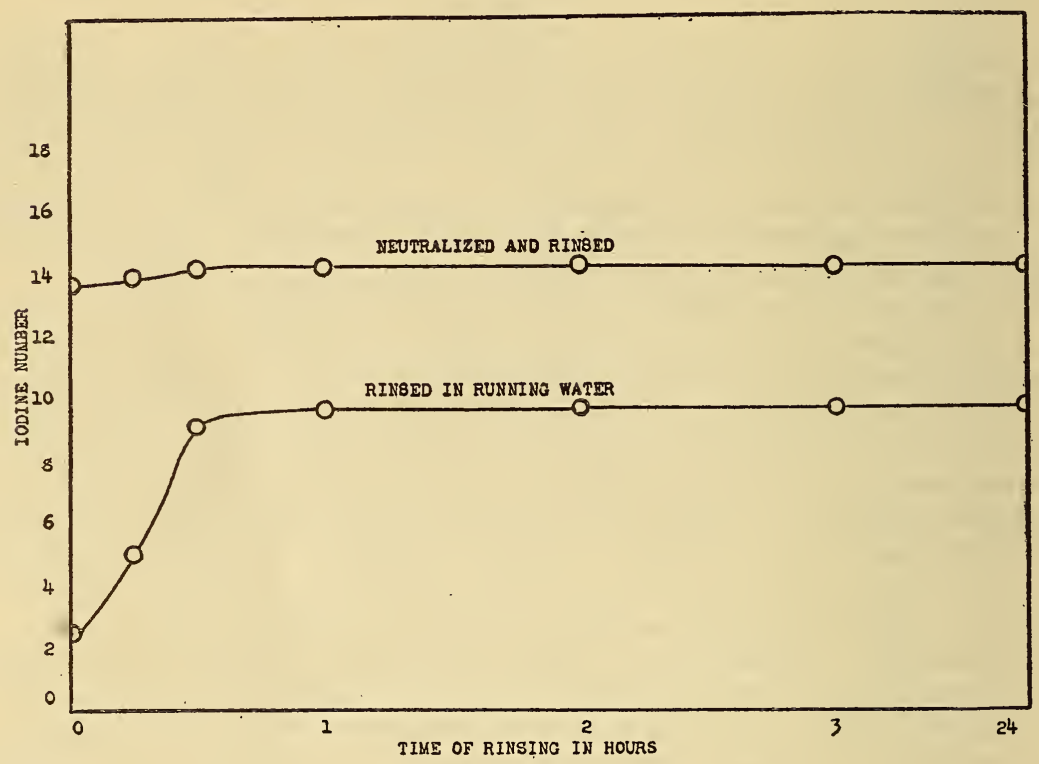

FIGURE 1.-The effects of (a) rinsing, and (b) neuiralizing plus rinsing of wool previously soaked in normal sulphuric acid, as shown by the iodine numbers.

38 C. Separate one-gram samples of wool were treated with $100 \mathrm{ml}$ of 0.5 normal sodium hydroxide solution for each test. At the time intervals indicated two samples were neutralized with acetic acid. One was evaporated to dryness at $60 \mathrm{C}$ under reduced pressure and the iodine number of the residue was determined. The amino nitrogen content of the other sample was determined by the Van Slyke method. Although the wool fibers appear to be dissolved in the sodium hydroxide solution at the end of 2 hours, the results of the Van Slyke analysis show that only partial hydrolysis of the wool has been accomplished even at the end of 36 hours. The iodine number rises rapidly during the first hour and becomes constant after 8 hours. The results show that the determination of the iodine number is not a measure of the hydrolytic breakdown of wool. 
The examples and suggestions given above show the applicability of the method for a number of purposes. Further study may increase the accuracy and utility of the method.

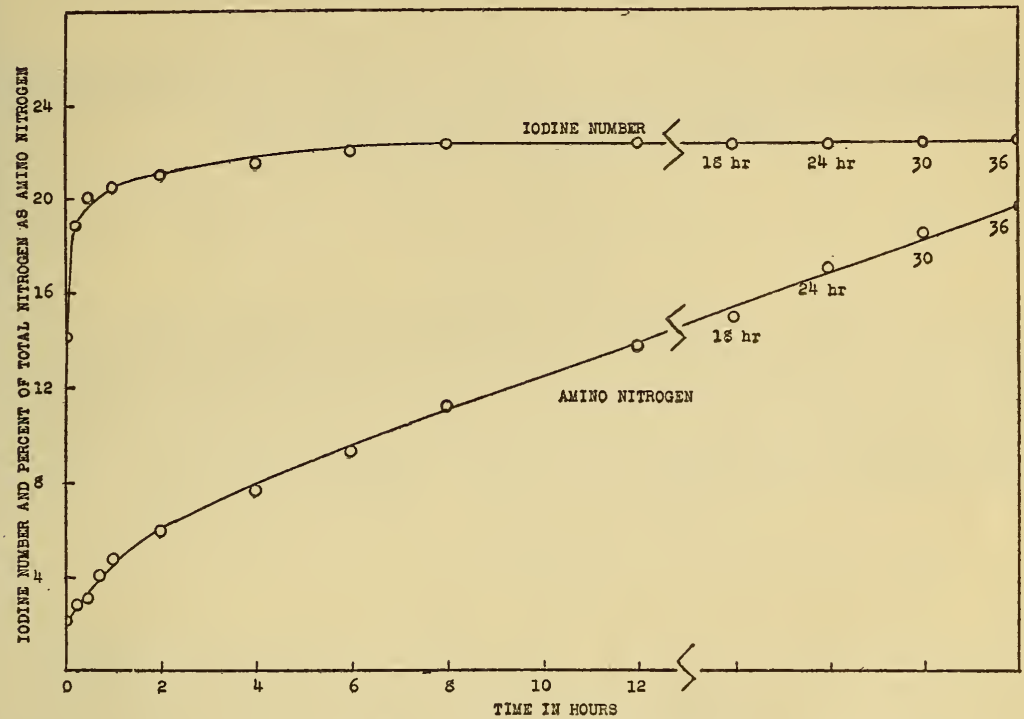

FIGURE 2.-The effects upon the iodine number and free amino nitrogen content of wool produced by continued action of 0.5 normal sodium hydroxide solution at $38 \mathrm{C}$.

\section{REFERENCES}

1. Methods of Analysis of the Association of Official Agricultural Chemists, $3 \mathrm{~d}$ edition, p. 73 .

2. C. C. Lucas and E. J. King, the Iodimetric Titration of Cysteine and Allied Substances, Biochem. Jour., vol. 26, p. 2076, 1932.

3. H. Phillips, The Formation and Constitution of Protein Salts From the Standpoint of Modern Theories of Valency, Jour. Intl. Soc. Leather Trade Chemists, vol. 17, pp. 151-165, 1933.

4. A. P. Mathews, Physiological Chemistry, pp. 122-123, 1916, Wm. Wood \& Company.

5. M. Harris, The Isoelectric Point of Silk, B.S.Jour. Research, vol. 9, pp. 557-560, 1932.

6. M. Harris, The Isoelectric Point of Wool, B.S.Jour. Research, vol. 8, pp. 779-786, 1932.

7. L. Michaelis and Grineff. Naturwissenschaften, vol. 18, p. 447, 1930.

8. F. A. Csonka, J. C. Murphy, and D. B. Jones, The Isoelectric Points of Various Proteins, Jour. Am. Chem. Soc., vol. 48, pp. 763-768, 1926.

9. M. Harris - Unpublished report.

10. Meunier and Rey, Sur les Proprietes de la Laine, Jour. Soc. Leather Trade Chemists, vol. 11, p. 508, 1927.

11. J. B. Speakman and M. C. Hirst, The Constitution of the Keratin Molecule, Trans. Faraday Soc., vol. 29, pp. 148-164, 1933.

12. D. D. Van Slyke and F. J. Birchard, Jour. Biol. Chem., vol. 16, p. 539, 1931.

Washington, April 3, 1934. 